\title{
Biotransformation of Khellin to Khellol by Aspergillus Niger and the Evaluation of their Biological Activities
}

\author{
Ahmed Ashour ${ }^{1,2}$, Saleh El-Sharkawy ${ }^{2,3}$, Mohamed Amer ${ }^{2}$, Fatma Abdel Bar ${ }^{2}$, Amira Mera ${ }^{1,2}$, \\ Toshiro Nagata ${ }^{1}$, Ryuichiro Kondo ${ }^{1}$ and Kuniyoshi Shimizu ${ }^{1, *}$ \\ ${ }^{1}$ Department of Agro-environmental Sciences, Faculty of Agriculture, Kyushu University, 6-10-1 Hakozaki, Higashi-ku, \\ Fukuoka 812-8581 Japan \\ ${ }^{2}$ Department of Pharmacognosy, Faculty of Pharmacy, Mansoura University, Mansoura 35516, Egypt \\ ${ }^{3}$ Department of Pharmacognosy, Faculty of pharmacy, Delta University for Science and Technology, Egypt
}

\begin{abstract}
Biotransformation of khellin using Aspergillus niger ATCC 10549 resulted in the production of khellol. The biological activities of the transformed product and khellin were established by antioxidant and acetylcholine esterase inhibitory assays. Khellol exhibited a higher degree of antioxidant and acetylcholine esterase inhibitory activities compared to khellin. This is the first report on the biotransformation of khellin by microorganisms and the first evaluation of the neuroprotective activity of either khellin or khellol.
\end{abstract}

Keywords: Biotransformation. khellin, khellol, neuroprotective.

\section{NTRODUCTION}

Microbial transformations have been widely exploited in the preparation of many useful chemical products [1-3]. Khellin is an active compound extracted from Ammi visnaga Lam (Fam. Apiaceae), which is natural source of several furochromones. Khellin has been reported to have some biological effects such as relaxation of smooth muscle [4] and prevention of stone formation associated with hyperoxaluria [5], but no evidence concerning antioxidant or neuroprotective effects (acetylcholine esterase inhibitory activity) has been reported. This report describes the microbial transformation of khellin to khellol, and the antioxidant and neuroprotective evaluations of the metabolite.

\section{MATERIALS AND METHODS}

\section{Plant Material}

Khellin was isolated and purified from unused parts of Ammi visinaga grown in Egypt. Its identity and chemical structure was confirmed by comparative study to those cited in the literature [6].

\section{General Experimental Procedures}

Melting points were determined on a Fisher-Johns Scientific Co. melting point apparatus, USA. The ${ }^{1} \mathrm{H}-{ }^{13} \mathrm{C}-$, APT, DEPT NMR spectra were analyzed on JEOL JNM ECA at $400 \mathrm{MHz}$ for ${ }^{1} \mathrm{H}$ - and $100 \mathrm{MHz}$ for ${ }^{13} \mathrm{C}$-NMR spectra. TLC

*Address correspondence to this author at the Department of Agroenvironmental Sciences, Faculty of Agriculture, Kyushu University, 6-10-1 Hakozaki, Higashi-ku, Fukuoka 812-8581 Japan;

E-mail: shimizu@agr.kyushu-u.ac.jp was performed on aluminum sheets precoated with $0.2-\mathrm{mm}$ silica gel 60 F254 (Merck). Plates were developed in a solvent mixture of $n$-hexane-ethyl acetate $(3: 7, \mathrm{v} / \mathrm{v})$, and the developed chromatograms were visualized under 254- and 365 -nm UV light and the spots were made visible by spraying with vanillin $/ \mathrm{H}_{2} \mathrm{SO}_{4}$ reagent before warming in an oven preheated to $110{ }^{\circ} \mathrm{C}$ for $5 \mathrm{~min}$ to develop yellow color for khellin and khellol.

\section{Microorganisms}

The microorganisms used in this work were provided by the culture collection of Mansoura University, Faculty of Pharmacy and were maintained on Potato-dextrose agar. The following microorganisms were screened for their ability to transform khellin: Aspergillus alliaceous UI 315, Aspergillus flavipes ATCC 11013, Aspergillus niger ATCC 10549, Aspergillus ochraceous NRRL 405, Bacillus cereus NRRLB14591, Congronella butleri ATCC 22822, Cunninghamella blakesleeana MR 198, Cunninghamella echinulata NRRL 1382, Cunninghamella elegans NRRL 1392, Penicillium chrysogenum ATCC 10002, Rhodotorula rubra NRRL 1592, Streptomyces flocculus ATCC 25453, Streptomyces rutgersensis BT 256, Penicillium chrysogenum ATCC 9480, Rhodotorula rubra NRRL 1592, Absidia glauca ATCC 22752, Acrothecium capsici ATCC 10714, Debaromyces polymorphus ATCC 20280, Mucor mucedo UI 315, Penicillium vermiculatum NRRL 10009 and Saccharomyces cerevisiae ATCC 2366.

\section{Fermentation Screening Procedure}

Using a two-stage fermentation protocol [7], screening was carried out by incubating the cultures while shaking at 200 rpm on New Brunswick Scientific G25 Gyratory shakers 
at $25{ }^{\circ} \mathrm{C}$ in a medium consisted of $2 \%$ glucose, $0.5 \%$ peptone, $0.5 \%$ yeast extract, $0.5 \% \mathrm{NaCl}$ and $0.5 \% \mathrm{~K}_{2} \mathrm{HPO}_{4}$, adjusted to $\mathrm{pH} 7.0$ before autoclaving for $15 \mathrm{~min}$ at $121{ }^{\circ} \mathrm{C}$. Stage I culture was started by suspending spores and mycelia from filamentous fungal culture slants in $2 \mathrm{~mL}$ of sterile medium and transferring the suspension to $25 \mathrm{~mL}$ medium contained in 150-mL flasks. After incubation for 72 hours, stage II cultures were initiated by transferring $2 \mathrm{~mL}$ of stage I cultures to $150-\mathrm{mL}$ flasks containing $25 \mathrm{~mL}$ medium. After 24 hours, khellin dissolved in dimethyl formamide $(0.2 \mathrm{mg} / \mathrm{mL}$ medium) was added to the flasks. Culture controls consisted of fermentation blanks in which the organisms were grown under identical conditions but without substrate addition. Substrate controls were composed of a sterile medium to which the substrate was added and incubated without microorganisms. Samples $(0.5 \mathrm{~mL})$ of stage II cultures were extracted with EtOAc $(2 \mathrm{~mL} \times 3)$ every $24 \mathrm{hr}$ for 15 days. The combined extracts were dried over anhydrous $\mathrm{Na}_{2} \mathrm{SO}_{4}$ and evaporated in vacuum at $40{ }^{\circ} \mathrm{C}$. The dried extracts were reconstituted in $0.5 \mathrm{~mL} \mathrm{MeOH}$, applied to silica gel plates. The results of TLC analysis of EtOAc extracts of the culture broths of all microbes showed that Aspergillus niger ATCC 10549 could metabolize khellin to more polar metabolites after fourteen days. The fermentation screening procedures were repeated using Aspergillus niger ATCC 10549 to prove the reproducibility of the metabolite formation.

\section{Scaled-up Reaction by Aspergillus Niger ATCC 10549}

Khellin (500 mg) was evenly distributed among 25 (150$\mathrm{mL}$ flasks), each containing $50 \mathrm{~mL}$ medium of 24-hr A. niger stage II cultures. The cultures were incubated for fourteen days $\left(200 \mathrm{rpm}, 25^{\circ} \mathrm{C}\right)$ and extracted with EtOAc $(1 \mathrm{~L} \times 3)$. The combined extracts were dried and evaporated to yield $430 \mathrm{mg}$ yellow viscous residue. The residue was mixed with $400 \mathrm{mg}$ of silica gel and placed on top of a silica gel column $(100 \mathrm{~g}, 1.5 \times 72 \mathrm{~cm})$. The column was isocratically eluted with $40 \%$ ethyl acetate in hexane. Fractions with identical $\mathrm{R}_{f}$ (TLC) were pooled.

\section{Biological Evaluation}

\section{Acetylcholine Esterase Inhibitory Assay}

AChE activity was measured using a microplate reader [8-9]. Acetylcholine esterase enzyme hydrolyzes the substrate acetylthiocholine, resulting in the product thiocholine, which reacts with Ellman's reagent (5,5-dithiobis [2nitrobenzoic acid; (DTNB) to produce 2-nitrobenzoate-5mercaptothiocholine and 5-thio-2-nitrobenzoate, which can be detected at $405 \mathrm{~nm}$. One hundred microliters of Tris buffer $(50 \mathrm{mM}, \mathrm{pH}=8.0,0.1 \% \mathrm{BSA}$, to stabilize the enzyme), $10 \mu \mathrm{l}$ of $0.25 \mathrm{U} / \mathrm{mL}$ AChE enzyme, $10 \mu \mathrm{l}$ of $10 \mathrm{mM}$ DTNB, and $5 \mu \mathrm{l}$ of compound per well at their maximum solubility [final concentrations of $0.73 \mathrm{mM}(192.3 \mu \mathrm{g} / \mathrm{mL})$ for khellin and $0.78 \mathrm{mM}(192.3 \mu \mathrm{g} / \mathrm{mL})$ for khellol] were added to 96 -well plates, which were then incubated at $30^{\circ} \mathrm{C}$ for $5 \mathrm{~min}$; then, $5 \mu \mathrm{l}$ of $75 \mathrm{mM}$ acetylthiocholine was added to each well and the plate was incubated for an additional 10 min at $30{ }^{\circ} \mathrm{C}$, after which the absorbance was measured at $405 \mathrm{~nm}$. Galanthamine, $0.1 \mathrm{mM}(38.46 \mu \mathrm{g} / \mathrm{mL})$, was used as a positive control.
The percentage of inhibition was calculated using the following formula:

$$
(\%) \text { inhibition }=\frac{\left.\left(\mathrm{A}_{\text {Blank }}-\mathrm{A}_{\text {Blank 100\% }}\right)-\left(\mathrm{A}_{\text {Sample }}\right)-\mathrm{A}_{\text {SampleBlank }}\right)}{\left(\mathrm{A}_{\text {Blank }}^{3}\right)-(\text { Blank 100\% })} \times 100
$$

where $A_{B l a n k}$ is the absorbance of the blank in which the sample is replaced by buffer, $A_{\text {blank } 100 \%}$ is the absorbance of the blank in which the sample and enzyme are replaced by buffer, A sample is the absorbance of the sample, and A sampleBlank is the absorbance of the sample wells in which the enzyme is replaced by buffer.

\section{ORAC Assay}

The oxygen radical anti-oxidant capacity (ORAC) assay measures the free radical scavenging activity of the sample and its ability to prevent the oxidative degeneration of the fluorescence of fluorescein after being mixed with the peroxyl radical generator 2,2'azobis (2-amidino-propan) dihydrochloride (AAPH) at $37{ }^{\circ} \mathrm{C}$. The ORAC method was used as previously described, with 96-well plates [10]. Briefly, $200 \mu \mathrm{l}$ of 94.4-nM fluorescein was added to each $20-\mu 1$ sample, Trolox, and phosphate buffer to reach $75 \mathrm{mM}, \mathrm{pH} 7.4$ (as blank), and the mixture was incubated at $37^{\circ} \mathrm{C}$ for 10 min. Seventy-five microliters of $31.7 \mathrm{mM}$ AAPH was added to each well, and fluorescence degradation was measured for $90 \mathrm{~min}$ at $30-\mathrm{sec}$ intervals. Excitation at $485 \mathrm{~nm}$ and emission at $525 \mathrm{~nm}$ were measured using a FlexStation $3 \mathrm{Mi}$ croplate Reader (Molecular Devices, LLC, Sunnyvale, CA, USA), and data were managed by SoftMax Pro ${ }^{\circledR}$ 5.4.1 software. The standard curve was linear between 0 and $50 \mathrm{mM}$ Trolox.

\section{RESULTS AND DISCUSSION}

Microbial transformation of khellin by $A$. niger produced one major spot on TLC with an $\mathrm{R}_{f}$ value of 0.2 , which upon its isolation afforded a $150-\mathrm{mg}(30 \%)$ colorless needle of the metabolite. This compound was identified by ${ }^{1} \mathrm{H}-$ and ${ }^{13} \mathrm{C}$ NMR as well as co-chromatography with an authentic sample to be identified as khellol (Fig. 1). The data was further confirmed by consulting the literature [11]. Ellman's method was used to evaluate the neuroprotective activity through the inhibition of ACE by khellin and its metabolite at their higher concentration, $0.73 \mathrm{mM}(192.3 \mu \mathrm{g} / \mathrm{mL})$ for khellin and $0.78 \mathrm{mM}(192.3 \mu \mathrm{g} / \mathrm{mL})$ for khellol. Khellin showed weak inhibitory activity, $26.3 \%$, at a higher concentration, compared with the positive control, galanthamine $(0.1 \mathrm{mM}$, $38.46 \mu \mathrm{g} / \mathrm{mL}$ ), which showed $93.4 \%$ ACEI, while higher inhibition was observed for khellol, which was $46.5 \%$ at the highest concentration (Fig. 2).<smiles>COc1c2ccoc2c(OC)c2c(=O)cc(C)oc12</smiles>

khellin<smiles>COc1c2ccoc2cc2oc(CO)cc(=O)c12</smiles>

khellol
Fig. (1). Khellin and its metabolite khellol 


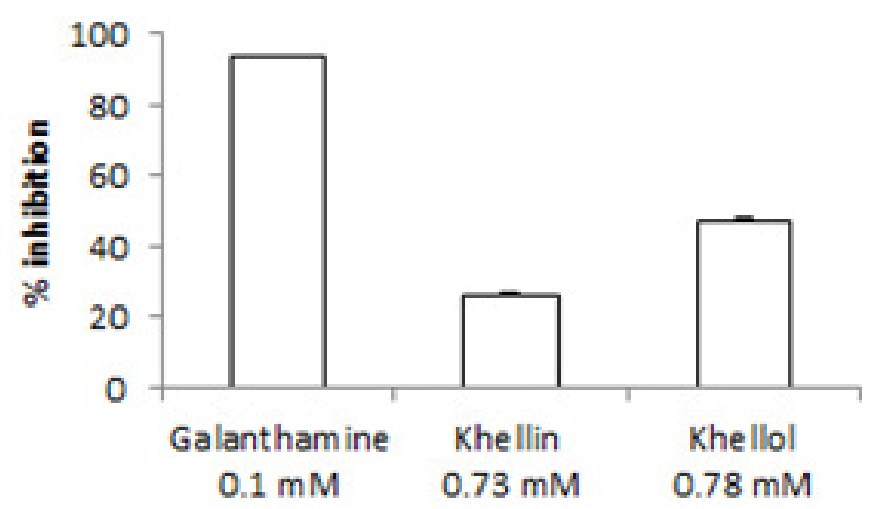

Fig. (2). Percentage of ACEI activity of khellin (0.73 mM, 192.3 $\mu \mathrm{g} / \mathrm{mL}$ ) and khellol $(0.78 \mathrm{mM}, 192.3 \mu \mathrm{g} / \mathrm{mL})$ (values $=$ means \pm $\mathrm{SD}, \mathrm{n}=4)$. Galanthamine $(0.1 \mathrm{mM}, 38.46 \mu \mathrm{g} / \mathrm{mL})$, used as a positive control, showed $93.4 \%$ inhibitory activity.

The results of ORAC assay (Table 1) showed khellol have higher antioxidant activity in comparison with khellin so it was concluded that the biotransformation of khellin greatly improved the neuroprotective and antioxidant activity through the formation of khellol as a metabolite. We also isolated khellol from the unused part of $A$. visinaga, proving that the plant metabolism mimics the microbial metabolism.

Table 1. Result of ORAC Assay

\begin{tabular}{|c|c|}
\hline Compound & ORAC value $(\mu$ mol Trolox-equivalent $/ \mathrm{g})$ \\
\hline Khellin & No activity (nealy 0$)$ \\
\hline Khellol & $332.1 \pm 7.7$ \\
\hline
\end{tabular}

\section{CONFLICT OF INTEREST}

The authors confirm that this article content has no conflicts of interest.

\section{ACKNOWLEDGEMENT}

The Egyptian Government is acknowledged for the fellowship support to Ahmed Adel Ashour.

\section{REFERENCES}

[1] Hufford, C.; Badria, F.; Abou-Karam, M.; Shier, W.;Rogers, R. Preparation, Characterization, and Antiviral Activity of Microbial Metabolites of Stemodin. J. Nat. Prod., 1991, 54, 1543-1552.

[2] Badria, F.; Hufford,C. Microbial transformations of stemodin, a Stemodia diterpene. Phytochemistry, 1991, 30 (7), 2265-2268.

[3] Beukers, R.; Marx, A.; Zuidweg, M. In: Microbial conversion as a tool in the preparation of drugs Ariens, E. J., Ed., Drug design, 3. Academic Press, Inc.: New York.1972.

[4] Kory, R.; Townes, A.; Mabe, R.; Dorris, E.; Meneely, G. Drug Evaluation in Angina Pectoris: Khellin, Heparin, Peritrate. Am Heart J., 1955, 50 (2), 308-321.

[5] Vanachayangkul, P.; Byer, K.; Khan, S.; Butterweck, V. An aqueous extract of Ammi visnaga fruits and its constituents khellin and visnagin prevent cell damage caused by oxalate in renal epithelial cells. Phytomedicine, 2010, 17(8-9), 653-658.

[6] Günaydin, K.; Beyazit, N. The chemical investigation on the ripe fruits of Ammi visinaga (Lam.) Lamarck growing in turkey. Nat. Prod. Res., 2004, 18 (2), 169-175.

[7] El-Sharkawy, S. Microbial conversion of tamoxifen. Appl. Microbiol. Biotechnol., 1991, 35, 436-439.

[8] Ellman,G.; Lourtney,D.; Andres, V.; Gmelin, G. A new and rapid colorimetric determination of acetylcholinesterase activity. Biochem. Pharmacol., 1961, 7, 88-95.

[9] Mukherjee, P.; Kumar,V.; Mal, M.; Houghton, P. In vitro acetylcholine esterase inhibitory activity of essential oil and its main constituents of Acorus calamus. Planta Med., 2007, 73, 283-285.

[10] Prior, R.; Hoang, H.; Gu, L.; Wu, X.; Bacchiocca, M.; Howard, L.; Hampsch-Woodill, M.; Huang, D.; Ou, B.; Jacob, R. Assays for hydrophilic and lipophilic antioxidant capacity (oxygen radical absorbance capacity (ORACFL) of plasma and other biological and food samples. J. Agric. Food Chem., 2003, 51, 3273-3279.

[11] Abou-Mustafa, A.; Saleh, M.; Elgamal, A.; Shalaby, M.; Duddeck, H. Afurther contribution to the $\gamma$-pyrone constituents of Ammi visnaga fruits.Planta Med., 1990, 56(1), 134. 